\title{
Parçacık Sürü Zekası Optimizasyonu ile Mikroskobik Görüntülerin Segmentasyonunda Farklı Entropi Ölçülerinin Etkisi
}

\author{
Hülya DOĞAN ${ }^{* 1}$, Selen AYAS ${ }^{1}$, Eyüp GEDIKL $\dot{I}^{2}$, Murat EKİNCi ${ }^{1}$ \\ ${ }^{1}$ Karadeniz Teknik Üniversitesi, Mühendislik Fakültesi, Bilgisayar Mühendisliği Bölümü, 61080, Trabzon \\ ${ }^{2}$ Karadeniz Üniversitesi, Of Teknoloji Fakültesi, Yazılım Mühendisliği Bölümü, 61830, Trabzon
}

(Alınış / Received: 29.12.2016, Kabul / Accepted: 16.08.2017, Online Yayınlanma / Published Online: 21.10.2017)

\section{Anahtar Kelimeler \\ Parçacık Sürü Optimizasyonu, \\ Mikroskobik görüntülerin \\ segmentasyonu, \\ Kapur entropi, \\ Tsallis entropi, \\ Otsu siniflar arası varyans \\ entropi}

\begin{abstract}
Özet: Tüberküloz, bir mikobakteri türünün neden olduğu, tedavi edilmediğinde ölümcül olabilen bir hastalıktır. Tüberküloz hastalığının tanısı için Dünya Sağlık Örgütü (DSÖ) tarafından önerilen teşhis yöntemi mikroskobik incelemedir. Mikroskobik inceleme süreci laboratuvar uzmanları tarafından el-göz koordinesiyle gerçekleştirilmektedir. Bu yüzden süreç oldukça zaman almakta ve laborantın inceleme yaparken hata yapma olasılı̆̆ını artırmaktadır. Bilgisayar destekli mikroskobik tanı sistemleri laborantlar tarafından manual olarak gerçekleştirilen bu süreci otomatikleştirmektedir. $\mathrm{Bu}$ sayede bu süreçte karşılaşılan olumsuzlukların minimize edilmekte, tanımada laboranta olan bağımlılık azalmakta ve bakteri analiz süreçlerinde daha sağlıklı sonuçların elde edilmesi sağlanmaktadır. Bilgisayar destekli mikroskobik tanı sistemlerinde tüberküloz bakterilerinin teşhisi için gerçekleştirilen ilk adım imge bölütlemedir. Bu çalışmada, mikroskobik görüntülerin bölütlenmesinde yeni bir yaklaşım olarak entropi tabanlı Parçacık Sürü Optimizasyonu (PSO) önerilmekte ve farklı entropi ölçülerinin sürece etkisi karşılaştırılmaktadır. Çalışmada gri seviyeye çevrilmiş görüntülerde uygun tek bir eşik değerinin belirlenme işlemi gerçekleştirilmiştir. Bu işlem için tek seviyeli Kapur entropi, Tsallis entropi ve Otsu sınıflar arası varyans entropi ölçüsü tabanlı parçacık sürü optimizasyonu kullanılmış ve bulunan optimum eşik değeri ile görüntü ikili görüntüye dönüştürülmüsstür. Elde edilen bölütleme sonuçları, uzman kişilerin el-göz koordinesiyle titizlikle belirledikleri bölütleme sonuçları ile karşılaştırılmıştır. Yapılan çalışmada farklı entropi ölçülerinin PSO ile mikroskobik görüntülerin bölütlenmesindeki etkisi gözlemlenmiştir. Ek olarak elde edilen sonuçların başarı performansları duyarlılık, özgüllük ve doğruluk değerleri ile nitel olarak karşılaştırılmış ve sonuçlar görsel olarak sunulmuştur.
\end{abstract}

\section{The Effect of Different Entropy Measures in Segmentation of Microscopic Images Using Particle Swarm Intelligence Algorithms}

\section{Keywords}

Particle Swarm Optimization,

Microscopic image

segmentation,

Kapur entropy,

Tsallis entropy,

Otsu between-class variance entropy

\begin{abstract}
Tuberculosis, caused by a micro bacterium, is a fatal disease when the disease is not treated. The proposed diagnosis method for the definitive diagnosis of the disease by World Health Organization (WHO) is a microscopic examination. The microscopic examination process is realized by laboratory experts by controlling hand-eye coordination. Therefore, this process consumes a lot of time and effects negatively on the diagnosis of disease and expert who performs the microscopic examination.Computer aided microscopy diagnostic systems automate this process which is performed manually by the laboratory experts. Thus, negativities encountered in this process are minimized, the dependency of the laboratory experts is reduced, and more reliable results in the bacterial analysis processes are obtained. The first step for the diagnosis of tuberculosis bacteria in computer-assisted microscopy diagnostic systems is image segmentation. In this study, entropy-based Particle Swarm Optimization (PSO) is proposed as a novel approach for segmentation of microscopic images and the effect of different entropy measures is compared. The selection of an optimum threshold value is performed in gray-level microscopic images. For this selection, the bi-level Kapur entropy, Tsallis entropy, and Otsu between-class variance entropy-based PSO are proposed and microscopic images are converted to a binary image using the selected optimum threshold value. Segmentation results are compared with expert-guided segmentation results. The effects of different entropy measures in a segmentation of microscopic images using PSO are observed. The segmentation results are compared qualitatively and presented quantitatively.
\end{abstract}

\section{Giriş}

Mikobakteri türlerinden biri olan mycobacterium tuberculosis dünya nüfusunun yaklaşık üçte birinde enfekte olan tüberküloz hastalığına yol açmaktadır [1]. Başlangıçta akciğerlerde görünen ve zamanla diğer organlara yayılan enfeksiyon hastalığ $\breve{1}_{1}$ erken tedavi edilmediği zamanlarda 
ölümle sonuçlanabilmektedir. [2]. Hastalığın teşhisi için çeşitli teknikler uygulanmaktadır. Dünya Sağlık Örgütü (DSÖ) tarafından hastalığın tanısı için bu teknikler arasından önerilen yöntem mikroskop ile Şekil 1'de gösterilen balgam yaymasının incelenmesidir. [3]. Doğru tanı için hastadan alınan balgam yayması örneğinde tüberküloz basillerinin (mikobakteri) gösterilmesi gereklidir. Dolayısıyla mikroskobik muayene oldukça önem taşımaktadır. Ziehl-Neelsen lekelendirme tekniği ile boyanan balgam yayma örneklerindeki tüberküloz basilleri mavi renk ile boyanmış doku üzerinde parlak kırmızı-pembe renkte görünmektedirler [4]. Günümüzde mikroskobik inceleme süreci labaratuvar uzmanları tarafından el-göz koordinesiyle yapılmakta ve balgam yaymasındaki her bir alanın en az 10-15 dakika incelenmesi gerektirmektedir. Numuneyi inceleyen kişinin tecrübesine de bağlı olan bu süreç zorluğa ve usandırıcılığa, hastalık için ise yanlış teşhis ve bulgulara neden olmakta ve dolayısıyla tedavinin hasta üzerinde olumsuz etkilerini ortaya çıkarmaktadır. Bilgisayar destekli mikroskobik tanı sistemleri laborantlar tarafindan el-göz koordinesiyle manual olarak gerçekleştirilen bu süreci otomatikleştirerek tüm bu olumsuz etkileri ortadan kaldırmaktadır. Bilgisayarla görmeye dayalı otomatik tanı sistemlerinde öncelikli işlem balgam yayması örneklerinin bulunduğu görüntülerin bölütlenmesidir. İmge bölütleme işlemi sistemin başarısında etkin rol oynamaktadır [5].

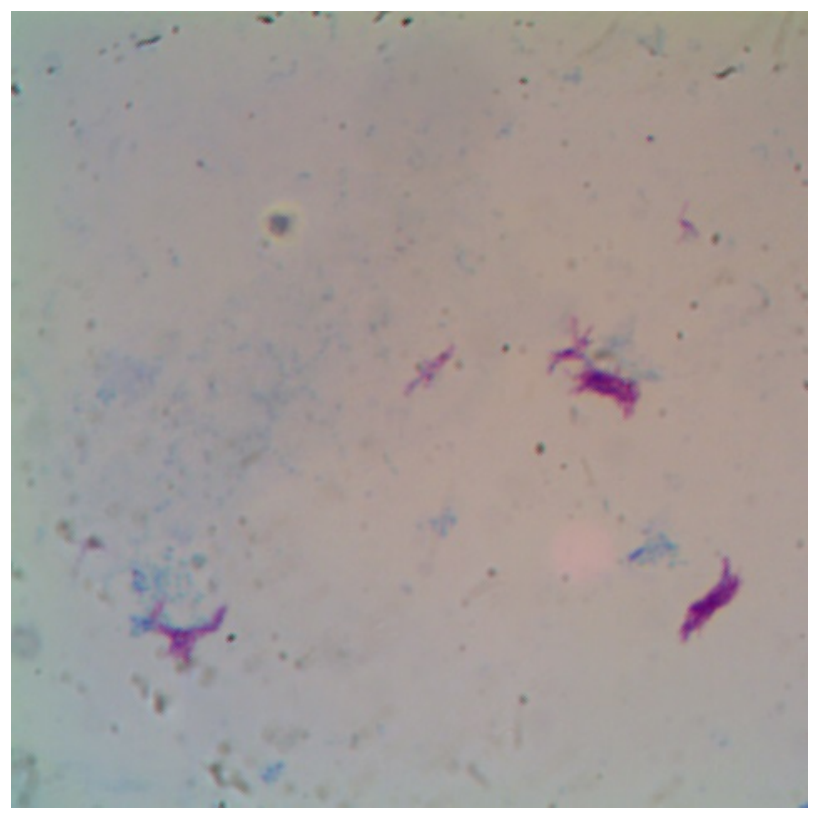

Şekil 1. Tüberküloz Basillerini İçeren Balgam Yayması Örneği

Tüberküloz hastalığının teşhisi ile ilgili literatürdeki yayınlar incelendiğinde, görüntü eşikleme algoritmalarının sıklıkla kullanıldı ̆̆ı görülmektedir. Burada önemli olan görüntüyü en iyi bölütleyecek eşik değerinin bulunmasıdır. Costa ve ark [6], RGB renk uzayındaki mikroskobik görüntüleri R-G uzayına taşıyarak adaptif eşikleme gerçekleştirmişlerdir. Raof ve ark. [7, 8], çok seviyeli eşikleme yöntemi kullanarak eşik değerleri, RGB ve HSI renk uzaylarının her bir kanalında deneysel olarak seçmişlerdir. Mevcut eşikleme yaklaşımları genel bir çözüm sunmayıp daha çok probleme özgü başarılı sonuçlar vermektedir. Ek olarak literatürde görüntü bölütleyen optimum eşik değerini bulmak için entropi tabanlı sürü zekası algoritmaları kullanılmıştır. Banerjee ve ark. [9] çalışmalarında PSO algoritması kullanarak görüntü segmentasyonu için optimum eşik değerini bulmayı amaçlamış ve uygunluk fonksiyonu olarak Kapur entropi ölçütünü kullanmışlardır. Brajevic ve ark. [10] yüksek hesaplama maliyetini azaltmak amacıyla Guguk Kuşu Algoritması tabanlı yeni bir çok seviyeli eşikleme metodu önermişlerdir. Çalışmada optimum eşik değerlerini bulmak için Kapur entropisi kullanılmış ve önerilen yöntem PSO ile karşılaştırılmıştır. Bouaziz ve ark. [11] iris algılama sürecini konu alan çalışmalarında çok seviyeli eşikleme için Kapur entropi tabanlı Yapay Arı Kolonisi algoritmasını önermişleridir. Çalışmada önerilen yöntemin başarısını ispatlamak için Guguk Kuşu ve PSO algoritmaları kullanılarak karşılaştırmalar yapılmıştır. Bhandari ve ark. [12] renkli görüntülerin segmentasyonu için Kapur entropisinden farklı olarak Tsallis entropi ölçütü tabanlı Guguk Kuşu algoritmasını kullanan yeni bir yaklaşım önermişlerdir. Çalışmada 10 farklı uzaktan algılama görüntüsü kullanılmış ve önerilen yöntem PSO ve Yapay Arı Kolonisi algoritmaları ile karşılaştırılmıştır. Agraval ve ark. [13] çok seviyeli eşikleme süreçlerinde optimum eşik değerini Guguk Kuşu algoritması ile Tsallis entropi değerini maksimumlaştırarak elde etmişlerdir. Önerilen bu yöntem Bakteriyel Besin Arama, Yapar Ar1 Kolonisi, PSO ve Genetik Algoritmalar kullanılarak karşılaştırılmış ve elde edilen sonuçlar nitel ve nicel olarak gösterilmiştir. Yapılan bazı çalışmalarda ise görüntü segmentasyon süreçlerinde optimum eşik değerini bulmak için geliştirilen optimizasyon algoritmaları Kapur entropisi kullanılarak karşılaştırılmıştır [14, 15]. Literatürde sürü zekası algoritmalarına dayalı görüntü eşikleme süreçlerinde kullanılan entropi çeşitlerini karşılaştıran çalışmalarda bulunmaktadır. Monic [16] çalışmasında Ateş Böceği algoritmasını kullanarak Kapur ve Tsallis entropi yöntemlerini, Bhandari [17] ise Yapay Arı Kolonisi, PSO ve Genetik algoritmaları kullanarak Tsallis, Kapur ve Otsu sinıflar arası varyans entropilerini karşılaştırmıştır.

Literatürde görüntü segmentasyon süreci için farklı optimizasyon algoritmaları kullanılarak optimum eşik değerini bulan çalışmalar önerilmiştir. Yapılan çalışmalarda genelde amaç fonksiyonu olarak Kapur, Tsallis ve Otsu sınıflar arası varyans entropileri kullanılmıştır. Bu çalışmada ise mikroskobik görüntülerin bölütlenmesinde farklı entropi çeşitlerinin etkisi incelenmiştir. $\mathrm{Bu}$ amaçla PSO algoritması kullanılarak Kapur, Tsallis ve Otsu sınıflar arası varyans entropi ölçüleri karşılaştırılmıştır. Çalışmada sonuçlar uzman kişiler tarafindan elle bölütlenen görüntülerle önerilen yaklaşım ile bölütlenen görüntüler karşılaştırılarak nitel olarak verilmiş ve görsel sonuçlar ile de desteklenmiştir.

Bu çalışma, 2. bölümde PSO algoritması, 3. bölümde kullanılan entropi ölçüleri, 4. bölümde önerilen yöntem ve son olarak deneysel sonuçlar şeklinde sunulmuştur. 


\section{Parçacık Sürü Optimizasyonu}

Parçacık sürü optimizasyonu Kennedy ve Eberhart tarafindan balık veya kuş sürülerinin yaşama ve hareket davranışlarından esinlenilerek geliștirilmiş popülasyon temelli sezgisel bir optimizasyon algoritmasıdır [18]. Sürüdeki bireyler yiyecek ararken birbirleriyle ve çevresiyle etkileşim halindedir. Herhangi birinin yiyecek bulması halinde diğerlerinin konumunu yiyeceğe doğru yönelttiği ve hızlarını da buna göre güncelledikleri görülmüştür. PSO bu sosyal etkileşimi temel almakta ve en iyi pozisyona yaklaşmayı amaçlamaktadır. Bu yaklaşma rastgele başlamakta ve en iyi pozisyona ulaşılana kadar önceki konu bilgileri kullanılarak sağlanmaktadır. Sürüdeki her birey bir parçacık olarak adlandırılmaktadır. PSO aşağıdaki işlem adımlarından oluşmaktadır.

1. Her parçacığa ait pozisyon $\left(x_{i}\right)$ ve hız $\left(v_{i}\right)$ rastgele üretilerek başlangıç sürüsü oluşturulur.

2. Her parçacığın uygunluk değeri hesaplanır.

3. Her parçacık için eşitlik (1) kullanılarak yerel en iyi pozisyon $\left(p_{i}\right)$ bulunur.

$p_{i}(t+1)=\left\{\begin{array}{ccc}p_{i}(t) & \text {,eğer } & f\left(x_{i}(t+1)\right) \geq f\left(p_{i}(t)\right) \\ x_{i}(t+1) & \text {,eğer } & f\left(x_{i}(t+1)\right)<f\left(p_{i}(t)\right)\end{array}\right.$

4. Önceki adımda belirlenen parçacıkların sahip olduğu yerel en iyi pozisyonların arasından eşitlik (2) kullanılarak genel en iyi pozisyon $\left(z_{i}\right)$ belirlenir.

$$
\begin{aligned}
z_{i}(t) \in\left\{p_{1}(t), p_{2}(t), \ldots, p_{m}(t)\right\}= & \min \left\{f\left(p_{1}(t)\right), f\left(p_{2}(t)\right),\right. \\
& \left.\ldots, f\left(p_{m}(t)\right)\right\}
\end{aligned}
$$

5. Parçacıkların pozisyon ve hızları eşitlik (3) ve (4) kullanılarak güncellenir.

$$
\begin{aligned}
v_{i}(t+1)= & w v_{i}(t)+c_{1} r_{1}\left(p_{i}(t)-x_{i}(t)\right) \\
& +c_{2} r_{2}\left(z_{i}(t)-x_{i}(t)\right)
\end{aligned}
$$

Eşitlik (3)'te w eylemsizlik katsayısını, $c_{1}$ ve $c_{2}$ ivmelenme katsayılarını ifade etmekte; $r_{1}$ ve $r_{2}$ ise $[0,1]$ aralığında rastgele üretilmektedir.

$$
x_{i}(t+1)=x_{i}(t)+v_{i}(t+1)
$$

6. Durdurma kriteri sağlanana kadar önceki adımlar (2, $3,4,5)$ tekrarlanır.

\section{Entropi Ölçüleri}

Görüntü bölütleme süreçlerinde optimum eşik değerini belirlemek amacıyla entropi metotları kullanılmaktadır. $\mathrm{Bu}$ çalışmada Kapur, Tsallis ve Otsu sınıflar arası varyans entropi ölçüleri kullanılmıştır.

\subsection{Kapur entropi ölçüsü}

Kapur tarafından geliştirilmiş entropi metodu [19], görüntü segmentasyon süreçlerinde optimum eşik değerini belirlemek için amaç fonksiyonu olarak kullanılmaktadır. Tek seviyeli eşiklemede görüntüyü arka ve ön bölgeye ayıracak eşik değeri belirlenmektedir. Kapur entropi metodunda optimum eşik değerini bulmak için her bölge entropisi ayrı ayrı hesaplanmakta ve maksimum olan seçilmektedir.

$\mathrm{N}$ tane piksel değerine sahip herhangi bir imgenin $\mathrm{G}$ gri seviyeli $0,1,2, \ldots, G-1$ olduğu düşünüldüğünde imgedeki gri seviye değerlerinin olasılıkları $P_{i}$, eşitlik (5) kullanılarak ifade edilmektedir.

$$
P_{i}=h(i) / N
$$

Eşitlik (5)'de; $h(i)$ imgedeki i gri seviyesine sahip piksel sayısını göstermektedir. Bölütleme işleminde $\mathrm{k}$ adet eşik değeri olduğu düşünülürse amaç fonksiyonu eşitlik (6 ve 7) kullanılarak hesaplanmaktadır. Yapılan çalışmada tek seviyeli eşikleme gerçekleştirileceğinden $k=1$ olarak alınmıştır.

$$
\begin{array}{cc}
f(t)=\arg \max \left(\sum_{i=0}^{k} H_{i}\right) \\
\omega_{0}=\sum_{i=0}^{t_{1}-1} P_{i} \quad H_{0}=-\sum_{i=0}^{t_{1}-1} \frac{P_{i}}{\omega_{0}} \ln \frac{P_{i}}{\omega_{0}} \\
\omega_{1}=\sum_{t=t_{1}}^{t_{2}-1} P_{i} \quad H_{1}=-\sum_{t=t_{1}}^{t_{2}-1} \frac{P_{i}}{\omega_{0}} \ln \frac{P_{i}}{\omega_{0}} \\
\omega_{2}=\sum_{t=t_{2}}^{t_{3}-1} P_{i} & H_{2}=-\sum_{i=t_{2}}^{t_{3}-1} \frac{P_{i}}{\omega_{2}} \ln \frac{P_{i}}{\omega_{2}} \\
\ldots & \ldots \\
\omega_{k}=\sum_{i=t_{k}}^{t_{k}-1} P_{i} & H_{k}=-\sum_{i=t_{k}}^{t_{k}-1} \frac{P_{i}}{\omega_{k}} \ln \frac{P_{i}}{\omega_{k}}
\end{array}
$$

\subsection{Tsallis entropi ölçüsü}

Tsallis entropi metodu [13] Shonnon teorisi temel alınarak elde edilmiş ve eşitlik (8) kullanılarak tanımlanmıştır.

$$
S_{q}=\frac{1-\sum_{j=1}^{E D}\left(p_{j}\right)^{q}}{q-1}
$$

Eşitlik (8)'de ED eşik değerini, $p_{j}$ ayrık parlaklık seviye sayısını, $q$ ise entropi indeksini göstermektedir. Herhangi bir görüntünün $\mathrm{G}$ gri seviyeli $0,1,2, \ldots, G-1$ olduğu düşünüldüğünde görüntüdeki gri seviye değerlerinin olasılıkları $\left(P_{i}=p_{0}, p_{1}, p_{2}, p_{L-1}\right)$ eşitlik (9) kullanılarak hesaplanmakta ve Tsallis çok seviyeli eşikleme eşitlik (10)'daki gibi ifade edilmektedir.

$$
\begin{gathered}
P_{i}={ }^{h(i)} /{ }_{N} \\
J_{\max }= \\
=\arg \max \left[S_{q}^{A}(E D)+D_{1}, E D_{2}, \ldots, E D_{k}\right] \\
\left.+(1-q)+\ldots+S_{q}^{A}(E D) . S_{q}^{B}(E D) \ldots S_{q}^{K}(E D)\right]
\end{gathered}
$$


Çok seviyeli eşiklemede maksimum F(ED) fonksiyon sonucuna sahip olan değer optimum eşik değeri olarak alınmaktadır. Yapılan çalışmada tek seviyeli eşikleme yapıldığından $T h=1$ ve $p_{A}, p_{B}$ alınmıştır.

\subsection{Otsu sınıflar arası varyans entropi ölçüsü}

Sınıflar arası varyansa dayalı bölütleme, Otsu yöntemini kullanan ve parametrik olmayan bir tekniktir [19]. Görüntüyü birden çok bölgeye ayırmak için kullanılmakta ve ayırdığı bölgelerin varyansını maksimumlaştırmaya dayanmaktadır. Otsu tarafından 1979 yılında önerilen sınıflar arası varyans eşitlik (11)'de görüldüğü gibi her sınıfın sigma fonksiyonlarının toplamı olarak tanımlanmaktadır.

$$
\begin{gathered}
f(t)=\sigma_{0}+\sigma_{1} \\
\sigma_{0}=\omega_{0}\left(\mu_{0}-\mu_{T}\right)^{2} \quad \sigma_{1}=\omega_{1}\left(\mu_{1}-\mu_{T}\right)^{2}
\end{gathered}
$$

Eşitlik (12)'de $\mu$ görüntünün piksel değerlerinin ortalamasını ifade etmektedir. Tek seviyeli eşiklemede sınıflar arası ortalamalar eşitlik (13) kullanılarak hesaplanmaktadir.

$$
\mu_{0}=\sum_{i=0}^{t-1} \frac{i p_{i}}{\omega_{0}} \quad \mu_{1}=\sum_{i=t}^{L-1} \frac{i p_{i}}{\omega_{1}}
$$

Burada $\omega_{0}$ ve $\omega_{1}$, görüntünün eşik değerine ve eşik değerinden maksimum gri seviye değerine kadar olan piksel olasılıklarının toplamını vermektedir. Optimum eşik değeri sınıflar arası varyans fonksiyonunun maksimumlaştırılmasıyla eşitlik (14) kullanılarak elde edilmektedir.

$$
t^{*}=\arg \max (f(t))
$$

\section{4. Önerilen Yöntem}

Çalışmada mikroskobik görüntülerin bölütlenmesi amacıyla tek seviyeli entropi tabanlı PSO algoritması geliştirilmiştir. Yapılan çalışmada her parçacık için amaç fonksiyonu olarak entropi ölçüsü kullanılmaktadır. Bölütlenmiş görüntüde entropi ölçüsünü maksimum yapan eşik değeri optimum eşik değeri olarak kabul edilmektedir. Akış diyagramı Şekil 2'de verilen entropi tabanlı PSO'ya dayalı mikroskobik görüntülerde segmentasyon yaklaşımı aşağıdaki adımlardan oluşmaktadır:

1. Her parçacık için rastgele pozisyon ve hız üretilerek başlangıç sürüsü oluşturulur.

2. Eşik değerine göre imge bölütlenir.

3. Bölütlenmiş her imgenin entropi ölçüsü (amaç fonksiyon değeri) hesaplanır ve birbirleriyle karşılaştırılır.

4. Parçacıklar yeni konumlarına hareket ederler, parçacıkların amaç fonksiyon değerleri güncellenir.

5. İterasyon sayısına ulaşılmış ise süreç sonlanır, ulaşı1mamış ise adım 2'ye dönülür.

6. Elde edilen optimum eşik değerine göre görüntü bölütlenir.
Başlangıç sürüsünün oluşturulması

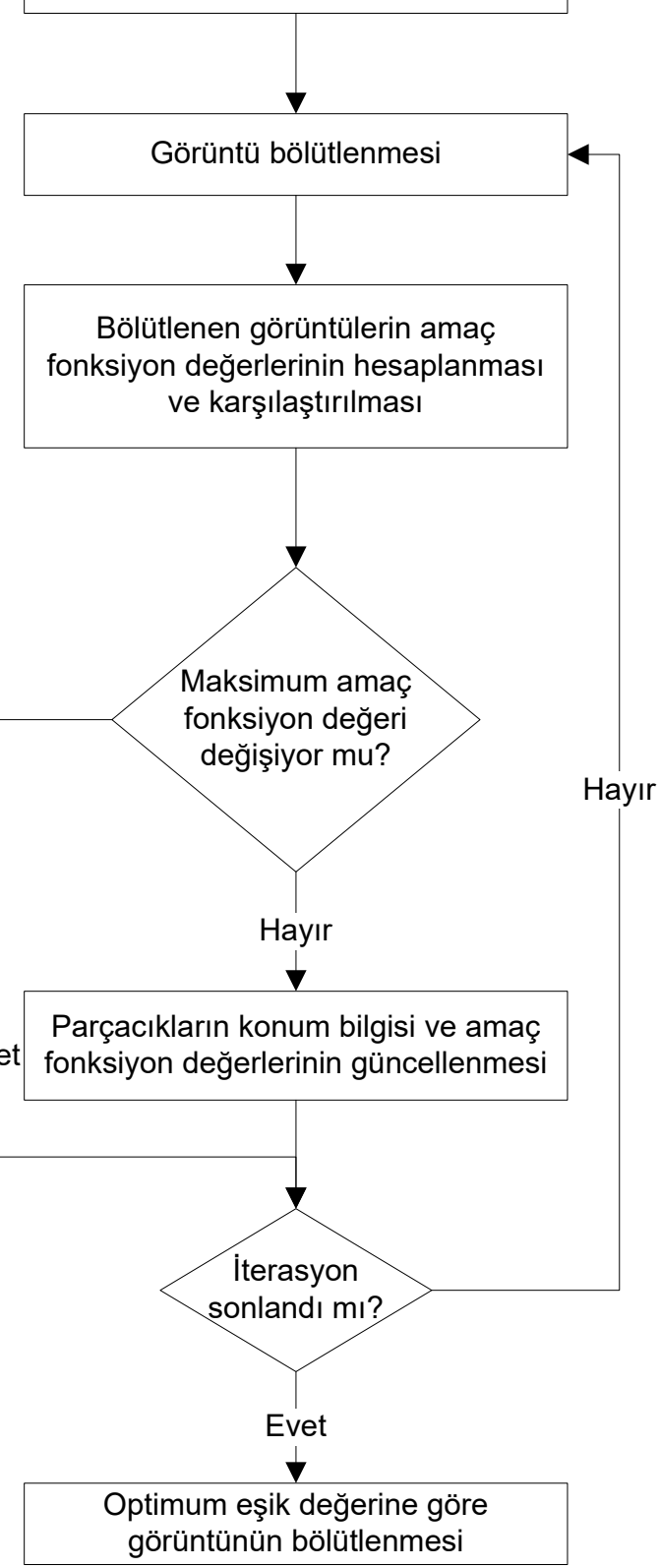

Şekil 2. Entropi Tabanlı PSO’ya Dayalı Mikroskobik Görüntülerde Segmentasyon Yaklaşımının Akış Diyagram1

\section{Deneysel Sonuçlar}

Çalışmada tüberküloz bakterilerinin belirlenmesi amacıyla, mikroskobik görüntülerin tek seviyeli bölütlenmesinde, farklı entropi ölçüleri tabanlı PSO algoritması kullanılarak entropi ölçülerinin bölütleme üzerinde nicel ve nitel karşılaştırılması yapılmıştır. Entropi ölçüleri amaç fonksiyonu olarak kullanılmış ve bölütlenmiş görüntüde entropi ölçüsünü maksimum yapan eşik değeri, en uygun eşik değeri olarak belirlenmiştir.

Ziehl-Neelsen lekelendirme tekniği ile boyanan pozitif 
Tablo 1. Kapur entropisi kullanılarak Parçacık Sürü Optimizasyonu algoritmasının optimum eşik değerleri, amaç fonksiyon değerleri, koşum süreleri (sn) ve duyarlılık, özgüllük, doğruluk \% sonuçları

\begin{tabular}{ccccccc}
\hline İmge & $\begin{array}{c}\text { Optimum eşik } \\
\text { değeri }\end{array}$ & $\begin{array}{c}\text { Amaç } \\
\text { fonksiyon } \\
\text { değeri }\end{array}$ & Koşum süresi & Duyarlıslık & Özgüllük & Doğruluk \\
İmge 1 & 132 & 7.2435 & 0,0295 & 92.40 & 99.22 & 99.17 \\
İmge 2 & 127 & 7.0159 & 0,0267 & 79.52 & 99.57 & 99.48 \\
İmge 3 & 130 & 6.7311 & 0,0271 & 79.98 & 99.38 & 99.27 \\
İmge 4 & 131 & 6.6765 & 0,0267 & 87.96 & 99.33 & 99.30 \\
İmge 5 & 138 & 6.4566 & 0,0268 & 95.72 & 99.21 & 99.20 \\
\hline
\end{tabular}

Tablo 2. Tsallis entropisi kullanılarak Parçacık Sürü Optimizasyonu algoritmasının optimum eşik değerleri, amaç fonksiyon değerleri, koşum süreleri (sn) ve duyarlılık, özgülllük, doğruluk \% sonuçları

\begin{tabular}{ccccccc} 
İmge & $\begin{array}{c}\text { Optimum eşik } \\
\text { değeri }\end{array}$ & $\begin{array}{c}\text { Amaç } \\
\text { fonksiyon } \\
\text { değeri }\end{array}$ & Koşum süresi & Duyarlı̧ık & Özgüllü̈k & Doğruluk \\
İmge 1 & 130 & 86.5770 & 0,0245 & 90.45 & 99.31 & 99.24 \\
İmge 2 & 128 & 77.7913 & 0,0247 & 80.99 & 99.53 & 99.45 \\
İmge 3 & 130 & 70.9453 & 0,0250 & 79.98 & 99.38 & 99.27 \\
İmge 4 & 131 & 67.1713 & 0,0252 & 87.96 & 99.33 & 99.30 \\
İmge 5 & 128 & 61.1713 & 0,02508 & 66.31 & 99.63 & 99.58 \\
\hline
\end{tabular}

Tablo 3. Otsu sınıflar arası varyans entropisi kullanılarak Parçacık Sürü Optimizasyonu algoritmasının optimum eşik değerleri, amaç fonksiyon değerleri, koşum süreleri (sn) ve duyarlılık, özgüllük, doğruluk \% sonuçları

\begin{tabular}{ccccccc} 
İmge & $\begin{array}{c}\text { Optimum eşik } \\
\text { değeri }\end{array}$ & $\begin{array}{c}\text { Amaç } \\
\text { fonksiyon } \\
\text { değeri }\end{array}$ & Koşum süresi & Duyarlılı & Özgüllük & Doğruluk \\
İmge 1 & 132 & 34.1641 & 0,0221 & 92.40 & 99.22 & 99.17 \\
İmge 2 & 154 & 24.5777 & 0,0227 & 100.00 & 56.05 & 56.23 \\
İmge 3 & 148 & 25.1928 & 0,0223 & 98.72 & 95.08 & 95.10 \\
İmge 4 & 155 & 18.1191 & 0,0227 & 100.00 & 52.93 & 53.04 \\
İmge 5 & 156 & 15.7273 & 0,0218 & 100.00 & 48.15 & 48.24 \\
\hline
\end{tabular}

yayma örnekleri, Karadeniz Teknik Üniversitesi Tıp Fakültesi Mikobakteriyoloji Laboratuvarında hazırlanmıştır. Ziehl-Neelsen lekelendirme tekniğinde aside-dirençli yapıları olan tüberküloz basilleri mavi renk ile boyanmış doku üzerinde parlak kırmızı-pembe renkte görülürler. Hazır preparatlardan görüntü almak için sistem Karadeniz Teknik Üniversitesi Bilgisayarla Görme Laboratuvarında [21] kurulmuştur. Sistem standart PC, mikroskop ve dijital kameradan oluşmaktadır. İki hastadan alınan iki adet pozitif yayma örneği Nikon Eclipse 80i 1şık mikroskobu ile 100x büyütme ile taranmıştır. Preimere Digital Microscope Eyepiece MA88-300 dijital kamera, görüntü almak için mikroskobun okülerine takılmıştır. Balgam yayma örneklerinden alınan 5 farklı görüntü 24 bit derinliğe sahip bitmap dosyası formatında, $480 \times 480$ piksel çözünürlüğünde kaydedilmiştir.

Bölütleme sonuçlarını değerlendirmek için ikili imgeler, uzman kişiler tarafindan elle bölütlenen imgelerle karşıllaştırılmış ve duyarlılık, özgüllük, doğruluk değerleri hesaplanmıştır. Uzman kişinin bölütlediği örnek bir imge Şekil 3'te verilmektedir. Kullanılan karşılaştırma metrikleri ise eşitlik (15), (16) ve (17)'deki gibi hesaplanmaktadır

$$
\text { Duyarlılık }=\frac{D P}{D P+Y N}
$$

$$
\begin{aligned}
& \ddot{O}_{z g u ̈ l l l u ̈ k}=\frac{D N}{D N+Y P} \\
& \text { Doğruluk }=\frac{D P+D N}{D P+Y P+Y N+D N}
\end{aligned}
$$

Eşitliklerdeki DP (doğru pozitif), gerçek pozitif kümeye dahil olup test sonucuna göre de pozitif çıkan durumu, YP (yanlış pozitif), gerçekte negatif kümeye dahil olup test sonucunun hatalı olarak pozitif çıktığı durum, YN (yanlış negatif), gerçekte pozitif kümeye dahil olup test sonucunun hatalı olarak negatif çıktığı durum ve DN (doğru negatif), gerçekte negatif kümeye dahil olup test sonucuna göre de negatif çıkan durumu göstermektedir.

Önerilen çalışmada kullanılan PSO algoritmasının ilgili parametrelerinin başlangıç değerleri deneysel olarak seçilmiştir. Popülasyon boyutu ve iterasyon sayısı parametreleri sırasıyla 10 ve 100 olarak verilmiştir. Algoritmanın diğer önemli parametrelerinden ivmelenme katsayıları 2, eylemsizlik katsayısı 0,9'dan 0,4'e lineer biçimde azalan sayllar ve $r_{1}, r_{2}$ ise rasgele sayllar olarak seçilmiştir. Çalışma Intel Core i7-4500U CPU, 4GB ram, 64-bitlik Windows işletim sistemi üzerinde MATLAB yazılımı kullanarak gerçekleştirilmiştir. Tablo 1,2 ve 
3 sirasıyla Kapur, Tsallis, Otsu sinıflar arası varyans entropi ölçüsü kullanılarak her bir test imgesi için PSO algoritması ile elde edilen optimum eşik değerlerini, amaç fonksiyon değerlerini, koşum sürelerini ve performans ölçümlerini göstermektedir.

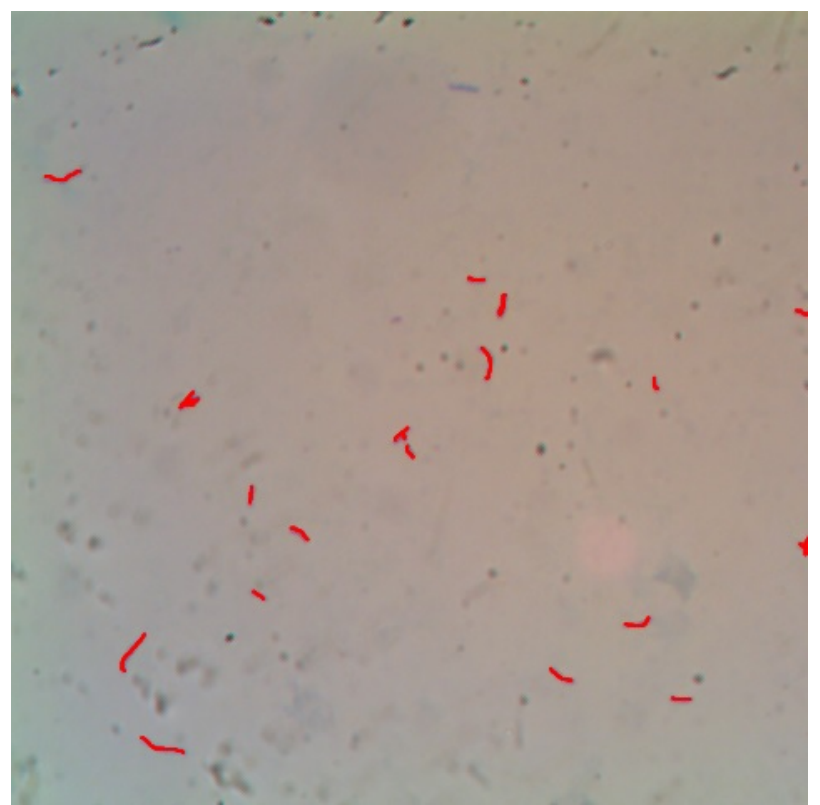

Şekil 3. Uzman Kişi Tarafından Bölütlenen Örnek imge

Tablo 1'in performans ölçümleri incelendiğinde duyarlılık değeri İmge 1, 4 ve 5 için oldukça yüksek iken İmge 2 ve 3 için yine makul düzeydedir. Kapur entropisinin amaç fonksiyonu olarak kullanıldığı bu deneyde özgüllük ve doğruluk değeri \%99 değerinin üzerine çıkarak oldukça yüksek performans göstermektedir. Tablo 2, Tsallis entropisinin amaç fonksiyonu olarak kullanıldığı deneyin sonuçlarını göstermektedir. İmge 3 ve 4 için Tablo 1 ile aynı performans ölçümleri elde edilmesine rağmen, İmge 1 için duyarlılık değeri düşmekte ve İmge 5 için bu değer oldukça fazla azalmaktadır. Bu deneyde yalnız İmge 3 için duyarlılık değeri Tablo 1'deki sonuçtan fazla elde edilmiştir, buna karşın özgüllük değeri daha düşüktür. Otsu sınıflar arası varyans kullanarak elde edilen sonuçların verildiği Tablo 3 incelendiğinde duyarlılık değerleri pozitif olarak görünse de özgüllük değerlerinin oldukça düşük olduğu görülmektedir. Bu yöntem ile sadece İmge 1 için anlamlı sonuç üretilmiştir. Şekil 1 test imgelerinin tek seviyeli eşikleme sonuçlarını göstermektedir. Görsel ve sayısal sonuçlar birlikte değerlendirildiğinde, Kapur entropisi kullanılarak elde edilen performansın diğer entropi ölçümlerine göre oldukça başarılı olduğu görülmektedir.

\section{Değerlendirme}

Bu çalışmada maksimum tek seviyeli entropi ölçüleri tabanlı PSO algoritması kullanılarak mikroskobik görüntülerin bölütlenmesi ve entropi ölçülerinin performanslarının karşılaştırılması amaçlanmıştır. Önerilen yaklaşımda mikroskobik imgelerin bölütlenmesi için kullanılacak olan optimum eşik değeri, amaç fonksiyonu olarak Kapur entropisi, Tsallis entropisi ve Otsu sinıflar arası varyans kullanılarak PSO algoritmasıyla belirlenmiştir. Sayısal sonuçlar Kapur entropisinin diğer kullanılan entropi ölçümlerine göre mikroskobik görüntüleri bölütlemede daha iyi performans elde ettiğini göstermektedir. Ayrıca görsel sonuçlar da sayısal sonuçları doğrulamaktadır.

\section{Kaynakça}

[1] WHO, 2015. Global Tuberculosis Report.

[2] Ayas, S., Ekinci, M. 2013. Detection of tuberculosis bacteria with microscopic image analysis. 21st Signal Processing and Communications Applications Conference (SIU), 24-26 April, Haspolat, 1-4.

[3] Central TB Division, 2005. Module for Laboratory Technicians, New Delhi.

[4] Ayas, S., Ekinci, M. 2014. Random Forest-Based Tuberculosis Bacteria Classification In Images Of ZnStained Sputum Smear Samples. Signal Image and Video Processing, 8, 49-61.

[5] Ayas, S.,Dogan, H., Gedikli, E, Ekinci, M. 2015. Microscopic image segmentation based on firefly algorithm for detection of tuberculosis bacteria. 23nd Signal Processing and Communications Applications Conference, 16-19 May, Malatya, 851-854.

[6] Costa, M. G. F., Filho, F. F. C., Sena, J. F., Salem, J. ve Lima, M. O. 2008. Automatic identification of mycobacterium tuberculosis with conventional light microscopy. 30th Annual International Conference of the IEEE Engineering in Medicine and Biology Society, 20-25 August, Vancouver, 382-385.

[7] Raof, R. A. A., Salleh, Z., Sahidan, S. I., Mashor, M. Y., Md Noor, S. S., Idris, ve M., Hasan, H. 2008. A Color thresholding method for image segmentation algorithm of ziehl-neelsen sputum slide images. 5th International Conference on Electrical Engineering, Computing Science and Automatic Control, 12-14 November, Mexico, 212-217.

[8] Raof, R. A. A., Mashor, M. Y., Ahmad, R. B., Noor, S. S. M., Osman, M. K. 2010. Comparison of colour thresholding method using RGB and HSI information for Ziehl-Neelsen sputum slide images. Proceedings of the sixth international symposium on micro machine and human science, 10-13 May, Kuala Lumpur, 724727.

[9] Banerjee, S., Jana, N. D. 2015. Bi level kapurs entropy based image segmentation using particle swarm optimization. Proceedings of the 2015 Third International Conference on Computer, Communication, Control and Information Technology, 7-8 February, Hooghly, $1-4$.

[10] Brajevic, I., Tuba, M., Bacanın N. 2012. Multilevel Image Thresholding Selection Based on the Cuckoo Search Algorithm. Advances in Sensors, Signals, Visualization, Imaging and Simulation, 7-9 September, Sliema, 217-222. 


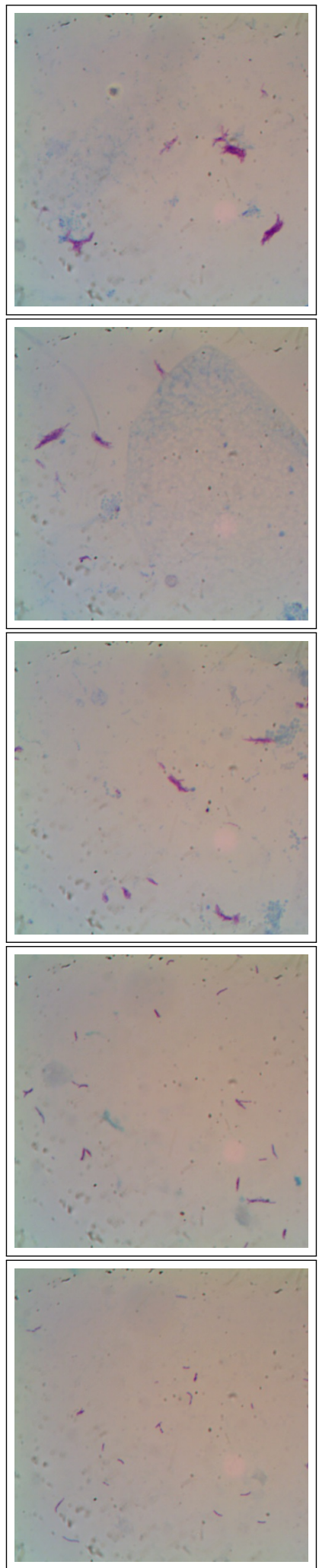

(a)

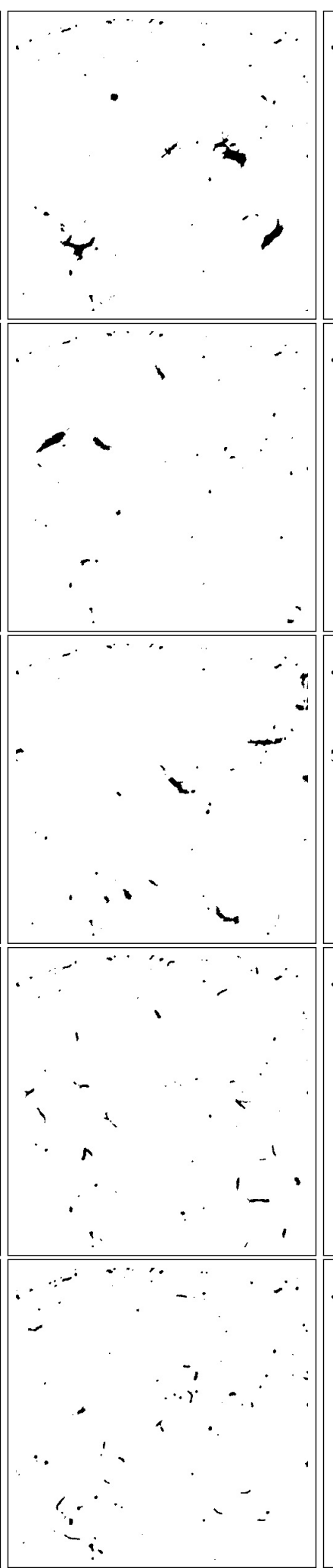

(b)

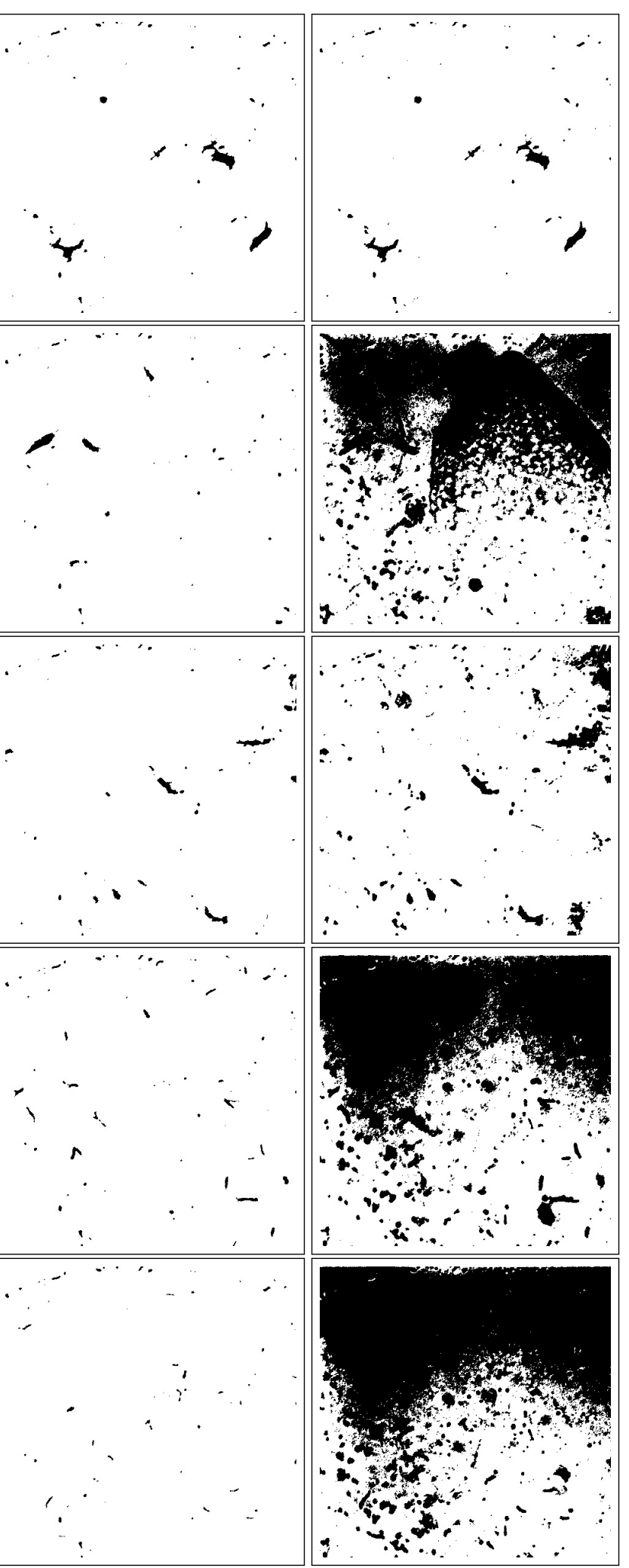

(c)

(d)

Şekil 4. Test imgeleri ve ilgili bölütlenmiş sonuçlar: (a) numune örnekleri, (b) Kapur entropisi, (c) Tsallis entropisi, (d) Otsu sınıflar arası varyans kullanılarak PSO ile bölütlenmiş sonuç imge görüntüleri

[11] Bouaziz, A., Draa, A., Chikhi S. 2015. Artificial bees for multilevel thresholding of iris images. Swarm and Evolutionary Computation, 21, 32-40.

[12] Bhandari, A. K., Singh V. K., Kumar A., Singh G. K. 2014. Cuckoo search algorithm and wind driven optimization based study of satellite image segmenta- tion for multilevel thresholding using Kapur's entropy. Expert Systems with Applications, 41, 3538-3560.

[13] Agraval, S., Panda, R., Bhuyan S., Panigrahi B. K. 2013. Tsallis entropy based optimal multi level thresholding using cuckoo search algorithm.Swarm and Evo- 
lutionary Computation, 11, 16- 30.

[14] Bhandari, A. K., Kumar, A., Singh G. K. 2015. Tsallis entropy based multilevel thresholding for colored satellite image segmentation using evolutionary algorithms. Expert Systems with Applications, 42, 87078730 .

[15] Kurban, T., Civicioglu P., Kurban R., Besdok E. 2014. Comparison of evolutionary and swarm based computationaltechniques for multilevel color image thresholding. Applied Soft Computing, 23, 128-143.

[16] Manic, K. S., Piriya, R. K., Rajinikanth V. 2016. Image Multithresholding based on Kapur/Tsallis Entropy and Firefly Algorithm. Indian Journal of Science and Technology, 9, 1-6.

[17] Bhandari, A. K., Singh V. K., Kumar A., Singh G. K. 2015. Modified artificial bee colony based computa- tionally efficient multilevel thresholding for satellite image segmentation using Kapur's, Otsu and Tsallis functions. Expert Systems with Applications, 42, 1573-1601.

[18] Eberhart, R., Kennedy, J. 1995. A new optimizer using particle swarm theory. 10th International Conference on Information Science, Signal Processing and their Applications, 4-6 October, Nagoya, 39-43.

[19] Kapur, J. N., Sahoo, P. K. ve Wong, A. K. C. 1985. A new method for gray-level picture thresholding using the entropy of the histogram. Computer vision, graphics, and image processing, 273-285.

[20] Otsu, N. 1979. A threshold selection method from gray-level histogram. IEEE transaction on systems, man and cybernetics , 62-66.

[21] http://ceng2.ktu.edu.tr/ cvpr/ 